contour. From their resemblance in shape to an elliptical convex lens, Professor Hitchcock has called them lenticular hills. The trend of their longer axis is always approximately parallel with the striæ marked upon the bed-rocks of the same region. These accumulations are scattered without any apparent order quite abundantly upon areas five to ten miles wide, and ten to twenty-five miles long. One of these areas includes Boston and its harbour, and extends five to fifteen miles on all sides of that city; while North-eastern Massachusetts and Southern New Hampshire have three belts of territory upon which these lenticular hills abound. These areas are separated by others of equal extent, which are entirely destitute of such accumulations of till, or show only occasionally one, quite typical and prominent, but isolated from all others of its kind.

These hills, like the valleys and the whole of New England, are overspread by the nearly universal mantle of the upper till, which is commonly between one and five feet in depth, but sometimes reaches to ten or twenty feet.

As this MAGAZiNe has formerly presented instructive comparisons of the superficial deposits in Great Britain and in America, I would like to inquire through its pages whether British geologists have noted accumulations of till like our lenticular hills.

Nashda, New Hampshire, April 14, 1879.

WARREN UPHAM.

THE GEOLOGICAL CONGRESS AT PARIS.

StR,-I am requested by an eminent foreign geologist to make the following additions and corrections with regard to the article on the International Geological Congress signed " $\AA$. L.," which appeared in the Geological Magazine for this month.

The Committee on Nomenclature inclnded Professor Dewalque of Liège as Secretary, Professor Hébert being its President. Since then, Professor Ferdinand Römer, of Breslau, has occupied the office of German representative.

Professor Hughes, of Cambridge, is entered as member of both Committees; this double appointment has been made since the Congress, and is contrary (as I am informed by the eminent geologist aforesaid) to the principles of the Congress. The complete absence of non-colonial Englishmen at the Congress was much discussed at the time, and the fact that a country like England should be unable to provide two geologists to join in the Universal Congress augurs but poorly for the success of the meeting at Bologna.

F. G. S. .

April $28 \mathrm{th}, 1879$.

\title{
BEEKITE FROM THE PUNJAB, INDIA.
}

SrR,-In a paper read before the Geological Section of the British Association held at Cheltenham, in 1856, Mr. W. Pengelly brought to notice a very remarkable and somewhat unique form of chalcedony, found plentifully in Torbay among the Triassic conglomerates, to which the name of Beekite has been given from Dr. Beeke, a former Dean of Bristol, by whom they were first publicly noticed. These Beekites consist of calcareous nuclei in a more or less advanced 
stage of decomposition incrusted with a thin surface of chalcedony arranged in tubercles, varying in size from a pin's head to a pea. These tubercles are surrounded by several rings, and frequently the same ring invests two or more tubercles. Occasionally the inclosed organism, which is either a Zoophyte or Mollusc, is found entirely decomposed and resolved into a few pinches of dust, and all that remains is the peculiarly mottled shell of chalcedony. In this case. the Beekite will float as easily as a blown egg. There is a very fine specimen of a floating Beekite to be seen in the Silica Group of the Horse Shoe Mineral Case in the Geological Museum in Jermyn Street. Mr. Pengelly is of opinion that this peculiar siliceous deposit is due to the decomposition of calcareous pebbles in Triassic conglomerate surrounded by water holding chalcedony in solution, which has been caught $n$ and deposited on the organic nucleus, the more readily from its being in a state of decomposition. The tubercular appearance may easily be accounted for from the appearance presented by a mass of fermenting and bubbling yeast. Thus the Beekite presents us with a most interesting stereotyped record of the evanescent, visible, and mechanical process of fermentation. Up to the present, I believe the range of this peculiar deposit is supposed to be restricted to the shores of Torbay, Australia, and the banks of the Nerbudda River in India. Mr. Pengelly, in the paper above referred to, gave it as his opinion that Beekites were only to be expected in conglomeratic rock containing decomposing calcareous pebbles, and through which water charged with chalcedony passes.

I have in my possession a very perfect specimen of Beekite which I found some years ago while travelling in an out-of-the-way part of India. It was on the slopes of Mount Sakesur, a high isolated peak forming the western extremity of the Salt Range in the Sind Sagar Doab of the Punjab; a locality fraught with the utmost interest to a naturalist, and especially so to a geologist, exhibiting, as it does, at a glance, almost a vast panoramic view of nearly all the typical palæontological forms familiar to European geologists, ranging from gigantic specimens of Brachiopodous shells, such as Spirifer, Strophomena and Productus, steadily up through Jurassic and Oolitic forms to those of the Eocene and Nummulitic Limestone. It was in the face of a precipitous cliff midway up the slopes of Mount Sakesur that I found my specimen deeply imbedded in a block of massive sandstone which had fallen from the overhanging cliff, which in itself consisted of a compact arenaceous formation of a dark grey colour literally teeming with Palæozoic fossils, such as the Productus, Spirifer, Rhynchonella, Lithostrotion basaltiforme, Crinoids, etc.

The specimen consists of a fragment of Productus shell, very probably Productus horridus - the formation itself being possibly Permian Magnesian Limestone. It is coated over with a crust of Chalcedony possessing identically the same tubercular structure met with on the specimens from Devonshire. As far as is as yet known, the geographical range of Beekites is in a limited area. The discovery, therefore, of my specimon in the Punjab Salt Range may possibly possess some interest to the question of distribution, coupled 
also with the fact that it was discovered in compact sandstone, instead of conglomerate. I shall be most happy to forward the specimen for the inspection of any one interested in the matter.

Junior Army and Navy Club.

H. W. Jamieson, Capt., F.R.G.S., Bengal Staff Corps.

\section{NOTE ON MR. LEE'S SPECIMENS OF FOSSIL WOOD FROM GRIQUA LAND.}

Sre,-The Lignite from Kimberly Mine, Claim 196, consists of stems, or branches converted into a brittle lignite, which still preserves the original size and form of the stems, and exhibits the internal structure peculiar to the Coniferm. The wood cells have a single series of discs, as in the wood of the recent Pines.

The specimens from Kimberly Mine, Claim 165, are more altered, and approach the condition of our Palæozoic coal. The small portions which show structure (mother-coal) consist of fragments of Coniferous wood, exhibiting the disciferous wood tissue with the discs in single rows.

The slides from the coal of Heilbron, Vaal River, Free State, consist of wood cells, with discs in single or double and opposite rows, as in the recent Pines.

W. Carruthers.

Botanical Department, British Museum.

GEOLOGY OF THE ISLE OF MAN.

SrR,-I examined in April, 1878, with Dr. Stolterfoth, of Chester, the Conglomerate of Langness in the Isle of Man, and can add my testimony to that of Mr. Morton (Geou. MaG., May, 1879), that Mr. Cumming was not mistaken in assigning them a position below the Carboniferous Limestone. Not only are they seen in the beach to dip under the Limestone, but the lower beds of the latter are themselves conglomeratic and interstratified with beds of red conglomerate, resembling those which occupy a large part of the promontory. Like Mr. Morton, I failed to find any limestone pebbles in the Conglomerates.

HOLYWELL, May 12, 1879.

A. Stratan.

[The following is a copy of a letter addressed to the Editor of the Times; published May 19th, 1879. Its contents are so important that we gladly take leave to reprint it in the Gkological Magazine.

-Edit. Grol. Mag.]

"Position of the Silurian Rocks in Herts.

"SIr,-In June. 1877, you did me the favour to insert in the Times the announcement and recognition by myself of the Devonian rocks in the deep boring at Messrs. Meux's Brewery, Tottenham-court-road, which there occurred below an abnormal condition of the Lower Greensand at the depth of 1,140ft. This announcement was at first received with doubt; nevertheless, the problem as to what was the nature of the Palæozoic rocks below London was there and then solved. Since then borings of greater diameter still have been put. down in other parts of the London Basin for the same purpose. 